ROCZNIK

TEOLOGII

KATOLICKIEJ

Tom VIII

Rok 2009

\title{
Johannes Hofman
}

Uniwersytet $w$ Eichstätt-Ingolstadt

\section{ZNACZENIE KOŚCIOŁA RZYMSKIEGO I JEGO BISKUPA DLA KOŚCIOŁA POWSZECHNEGO OD „KONSTANTYŃSKIEGO PRZEŁOMU” DO SOBORU CHALCEDOŃSKIEGO $(451)^{*}$}

\section{THE ROLE OF ROMAN CHURCH AND HIS BISHOP FOR THE UNIVERSAL CHURCH FROM THE CONSTANTINE BREAKTHROUGH TO THE CHALCEDON COUNCIL (451)}

The history of shaping institutional structures of the Church goes back to the beginnings of Christianity. However, the process of their emerging is associated with the so-called The Constantine Breakthrough in the year 312. This date marks the beginnings of 'visible' and identifiable Church structures which were built by bishops and based on the principle of mutual communion.

W poprzednim artykule zastanawialiśmy się nad awansem Rzymu i innych głównych Kościołów w pogańskim państwie rzymskim, którego rządowe organy jak i większość obywateli byli wrogo nastawieni do chrześcijan ${ }^{1}$. Te państwowe i społeczne ramy zmieniają się zasadniczo z nadejściem tzw. „przełomu konstantyńskiego", który chronologicznie łączy się ze zwycięstwem cesarza Konstantyna w roku 312.

\footnotetext{
* Artykuł autorstwa ks. prof. Johannes’a Hofmana jest kontynuacją jego rozważań opublikowanych w „Roczniku Teologii Katolickiej”, T. VII (2008), s. 272-290 pt.: Znaczenie rzymskich wspólnot chrześcijańskich i ich biskupa dla całego Kościoła w pierwszych trzech wiekach chrześcijaństwa. Niniejszy artykuł był drukowany w „Klerusblatt” 86(2006), s. 218-224.

1 Zob. Znaczenie rzymskich wspólnot, dz. cyt.
} 


\section{Wpływ tzw. przełomu konstantyńskiego na pozycję starych głównych Kościołów ${ }^{2}$ w Cesarstwie Rzymskim i na powstanie Konstantynopola ${ }^{3}$}

Ten „przełom” oddziałuje znacząco najpierw na Kościół rzymski. Odtąd chrześcijański cesarz ingeruje w sprawy kościelne i okazuje się wkrótce potężnym konkurentem biskupa rzymskiego. Do tego dochodzi w 330 roku założenie wschodniej stolicy Cesarstwa - Konstantynopola, której biskup mocno odeprze wpływ biskupa Rzymu na Wschodzie już po kilku dziesiątkach lat jej istnienia. Jednakże przesunięcie politycznego punktu ciężkości Cesarstwa na Wschód niosło ze sobą także i korzyści. Cesarz jest daleko, co umożliwia biskupowi Rzymu rozbudować jeszcze bardziej swój autorytet na Zachodzie. Ponadto unika on niebezpieczeństwa bycia zdegradowanym w podobny sposób jak niektórzy biskupi Konstantynopola do rzędu cesarskiego biskupa „dworskiego”.

Jaki więc wpływ wywiera obecnie chrześcijańskie państwo rzymskie na Kościół katolicki? Dotychczasowa communio pomiędzy lokalnymi Kościołami została utrzymane dzięki następującym instytucjom:

1. poprzez synody regionalne,

2. poprzez główne Kościoły Rzymu, Aleksandrii i Antiochii jako organizacyjne miejsca węzłowe communio,

3. poprzez autorytet Rzymu w sensie pewnego religijnego wyprzedzenia.

Te kościelne zwyczaje, opierające się na niezbyt jeszcze ustabilizowanych instytucjach, będą teraz w całym Cesarstwie dzięki soborowym dekretom prawnej natury bardziej umocnione poprzez tzw. kanony. W ten sposób sobór w Nicei z 325 roku reguluje po raz pierwszy na piśmie podane i obowiązujące w całym Cesarskie Rzymskim i w Kościele normy dotyczące kształtu i kompetencji synodów regionalnych i głównych Kościołów ${ }^{4}$.

Odnośnie do rzeczywistości synodów regionalnych postanawia się w kanonie 4., że - obok kleru i wiernych świeckich danego Kościoła lokalnego - biskupa lokalnego wybierają wszyscy biskupi prowincji kościelnej, podczas gdy potwierdzenie wyboru nowego biskupa przypada metropolicie, a więc biskupowi stołecznego miasta prowincji (metropolis). Podobnie też wszyscy biskupi prowincji, w razie zaś konieczności trzech biskupów, udzielają święceń nowemu biskupowi.

2 Pisane w artykule „Kościoły” dużą literą oznaczają, tworzące się wokół silnych ośrodków chrześcijańskich, takich jak Rzym, Aleksandria, Antiochia, Jerozolima i od IV wieku Konstantynopol, struktury kościelne nadające duże znaczenie ich stolicom; nie chodzi więc tutaj o świątynię, kościól, a chrześcijańską społeczność danego ośrodka na czele z biskupem i gronem prezbiterów i diakonów.

3 Por. K. Schatz, Der päpstliche Primat. Seine Geschichte von den Ursprüngen bis zur Gegenwart, Würzburg 1990, s. 36 i n.

4 Omawiane tu teksty kanonów 4., 6. i 7. Soboru Nicejskiego por. u. G. Alberigo i in. (red.), J. Wohlmuth (red. i przekł.), Conciliorum oecumenicorum decreta. Dekrete der ökumenischen Konzilien, T. I, Paderborn - München - Wien - Zürich 1998, s. 7-9. 
W ten sposób są ustalone obwody, zwane kościelnymi prowincjami, którym lokalni biskupi są przyporządkowani, a przestrzennie stają się one praktycznie identyczne z państwowymi prowincjami, na czele których każdorazowo stoi metropolita. Wpływ biskupów danej prowincji i ich metropolity rozciąga się odtąd na wyznaczanie lub przenoszenie biskupów trudnych do współpracy, jak też wywieranie wpływu na podejmowanie decyzji w sprawach wiary.

Kanon 6. Soboru Nicejskiego potwierdza na mocy prawa kościelnego dla całego Cesarstwa owe duże nadrzędne przestrzennie obszary jurysdykcyjne głównych Kościołów, na których czele stali już od dawna biskupi Rzymu, Aleksandrii i Antiochii, ale kanon 6. dokładnie opisuje tylko tereny należące do biskupa Aleksandrii. Kanon 7. przyznaje wprawdzie biskupowi Jerozolimy, miastu Pana, honorowy prymat (akoluthia tes times), jednak nie przyznaje mu żadnych pełnomocnictw, które wykraczałyby poza jego biskupią siedzibę.

Na soborze w Konstantynopolu dochodzą kolejne doprecyzowania dotyczące prawa kościelnego na obszarze Cesarstwa ${ }^{5}$. W kanonie 2. mówi się o kościelnych diecezjach (gr. dioikesis, łac. dioecesis) tzn. o terenach administrowania, które paralelnie pokrywają się z państwowymi obwodami administracyjnymi w przypadku większej liczy prowincji, zwanymi dioecesis. Biskupowi Aleksandrii będzie w tym systemie powierzona jurysdykcja nad diecezją Egiptu, biskupowi Antiochii nad diecezją Wschodu.

Kanon 3. zawiera pewną nowość, a mianowicie taką, że biskupowi Konstantynopola przysługuje po rzymskim biskupie tytuł "honorowego prymatu” (po gr. presbeja tes times; po łac. honoris primatus). Uzasadnia się to podniesieniem godności politycznym dowodem: „ponieważ to miasto jest nowym Rzymem” (kan. 2.). Ponieważ Konstantynopol jako „nowy Rzym” jest wschodnią, a „stary Rzym" - zachodnią stolicą Cesarstwa, stąd biskup Konstantynopola powinien posiadać, analogicznie do rzymskiego biskupa, wysokie stanowisko. Jest jasne, że główne Kościoły Wschodu wyróżniane od dawna jako takie, czują się teraz zepchnięte na plan dalszy przez nową siedzibę biskupią nad Bosforem, szczególnie Kościół w Aleksandrii, który na Wschodzie zawsze odgrywał wiodącą rolę. Także Rzym drażliwie reaguje na to przesunięcie kościelnych stosunków prawnych, gdy już na Synodzie Rzymskim w 382 roku podkreśla, „że święty Kościół rzymski jest wyróżniony spośród innych Kościołów nie przez synodalne decyzje, ale posiada ten prymat na podstawie słów naszego Pana i Zbawiciela wypowiedzianych w Ewangelii: «Ty jesteś Piotrem», [...]”6. Do tego dochodzi także osoba św. Pawła, który razem ze św. Piotrem poniósł męczeńską śmierć w Rzymie; obaj Apostołowie uświęcili więc jednocześnie rzymski Kościół

5 Teksty rozpatrywanych tu 2. i 3. kanonu Soboru Konstantynopolitańskiego por. przyp. 4.

6 Synod w Rzymie z roku 382 zob. u P.-P. Joannou, Die Ostkirche und die Cathedra Petri im 4. Jahrhundert (= PuP 3) Stuttgart 1972, s. 285 nr 89. Do tego synodalnego tekstu odnosi się też następna parafraza. Co do jej interpretacji synodalnego tekstu por. tamże, s. 285-289. 
Chrystusowy i na podstawie ich obecności i męczeństwa będą przewodzić wszystkim stolicom apostolskim na świecie. Tym Piotrowym uzasadnieniem powraca Synod do pierwotnej hierarchii głównych Kościołów i postanawia na podstawie teorii o trzech Piotrowych stolicach, że prymat przysługuje stolicom biskupim Rzymu, Aleksandrii i Antiochii na podstawie ustanowienia ich przez Piotra, a nie na podstawie kryteriów politycznych.

Pomimo tych zarzutów cytowane kanony stabilizują kościelną communio poprzez opisane i przez państwo sankcjonowane instytucje. $Z$ drugiej strony ta, ukierunkowana na regionalną, organizacja Kościoła niosła ze sobą niebezpieczeństwa, które mogły prowadzić do ograniczenia udziału tychże obwodów w duchowo okrojonej autonomii w stosunku do głównych Kościołów. To się okaże bardzo widoczne już podczas posoborowych kontrowersji w sprawie teologii aleksandryjskiego prezbitera Ariusza.

\section{Podjęcie decyzji przez biskupa Rzymu Juliusza w sprawie ogólnokościelnej współodpowiedzialności a przeciw regionalnej autonomii ${ }^{7}$}

Po tym jak sam Sobór Nicejski, organizowany dla Kościołów całego Cesarstwa, nie mógł zakończyć sporu o naukę Ariusza, także różne następne regionalne synody ariańskie nie były w stanie rozwiązać aktualnych teologicznych problemów i podjąć zadowalającego rozwiązania w kontrowersyjnych decyzjach personalnych. Tak więc wkrótce dochodzi do konfliktu, kiedy inne synody, szczególnie ten obradujący w Rzymie w 341 roku, ponownie rehabilitują usuniętych biskupów. Co jest więc teraz obowiązujące, jeżeli jakiś synod prowincjonalny anuluje to, co drugi postanowił? Powstają ciągłe sprzeczności od synodu do synodu i krystalizują się dwie różne pozycje ${ }^{8}$.

Biskupi wschodni, zwłaszcza ci obradujący na synodzie w 341 roku w Antiochii, są mocno przekonani o tym, że każdy synod regionalny posiada autonomię, a ich decyzje są ostateczne. Dlatego ani biskup, ani prezbiter, który zostanie potępiony przez jakiś synod, a chodziło tu o biskupa Atanazego Aleksandryjskiego, nie może odwoływać się do innego synodu.

Również w 341 roku obradujący w Rzymie synod regionalny zwrócił się przeciw tej próbie rozwiązania spraw na szczeblu regionalnym a odnoszących się w rzeczywistości do całego Kościoła, reprezentował stanowisko, że takie synodalne decyzje otrzymują ich prawomocność dopiero po uzgodnieniu z całym

7 Por. dalej K. Schatz, Primat, dz. cyt., s. 37-39; L. Perrone, Von Nicaea (325) nach Chalcedon (451), [w:] G. Alberigo (red.), Geschichte der Konzilien. Vom Nicaenum bis zum Vaticanum II, Düsseldorf 1993, s. 22-134; tu: 61 i n.; P. Stockmeier, Altertum, [w:] J. Lenzenweger i in. (red.), Geschichte der katholischen Kirche, Graz - Wien - Köln 1995 wyd. 3, s. 25-187; tu: 113 i n.

8 W sprawie wschodniego i rzymskiego rozumienia synodu zob. E. Caspar, Geschichte des Papstums von den Anfängen bis zur Höhe der Weltherrschaft, T. I, Tübingen 1930, s. 147-149. 
Kościołem. Jaką więc rolę przypisuje biskup rzymski Kościołowi powszechnemu, a jaką sobie samemu?

Biskup Rzymu Juliusz daje odpowiedź na to pytanie biskupom wschodnim, zwracając się do nich pismem synodalnym, gdy zaznacza, że mówi on w imieniu rzymskiego synodu z 341 roku (por. Juliusz Rzymski cytowany przez Atanazego, Apologia contra Arianos, 35). Według biskupa Juliusza jest konieczne, aby w bardzo ważnych decyzjach synodów, jak np. w tak ważnej sprawie personalnej, która dotyczy biskupa Atanazego z Aleksandrii, prawo głosu miały wszystkie Kościoły lokalne. Dotyczy to, jak w tym przypadku, jednego Kościoła głównego i Rzym musi być w tej sprawie koniecznie konsultowany. Przeciwko autonomicznym decyzjom synodów regionalnych przemawia także stary obyczaj, że ważne problemy zostają najpierw przedstawione wszystkim Kościołom lokalnym a dopiero potem niech „prawda przemówi przez wszystkich”. I ostatecznie Juliusz podkreśla, że on jako stróż dziedzictwa Apostołów Piotra i Pawła czuje się zmuszony do korygującej wypowiedzi, która służy tylko dobru wspólnoty kościelnej i stąd powinna znaleźć u adresatów dobre przyjęcie.

\section{Uznanie Rzymu na synodzie w Sardyce jako instancji rewizyjnej ${ }^{9}$}

Tak jak uczynił bp Juliusz, w przypadku biskupa Atanazego z Aleksandrii, podobnie jest podkreślone prawo głosu całego Kościoła. Jeżeli da się przełożyć reprezentowaną przez Juliusza linię na praktykę stosowaną w IV wieku, oznaczałoby to, że czas już dojrzał na przeprowadzenie soboru dotyczącego całego Cesarstwa, w którym wzięliby udział wszyscy biskupi. W rzeczywistości został taki sobór zwołany do Sardyki w 343 roku. Gdy biskupi ze Wschodu dowiedzieli się na miejscu, że ekskomunikowani przez nich biskupi występują razem z Atanazym jako ojcowie synodalni, natychmiast zażądali ich usunięcia. Przy tym dodają, że oni konsekwentnie reprezentują kościelną autonomię Wschodu niezależną od Zachodu i obstają przy tym, aby Zachód nie mieszał się w sporne sprawy Wschodu i odwrotnie. Zachodni biskupi natomiast stoją twardo za ekskomunikowanymi biskupami i odrzucają autonomię Wschodu. Synod więc już na wstępie podzielił się i spowodował wyjazd biskupów wschodnich. Zachodni uczestnicy synodu sami wyjaśniali dalej, co powinno wydarzyć się, jeżeli jeden z potępionych biskupów regionalnych chciałby zaskarżyć swoje potępienie.

$\mathrm{Na}$ ten problem odpowiedzieli oni kanonami od 3. do 5. synodu w Sardyce. Kanon 3. postanawia, że ekskomunikowany przez niektórych biskupów swojej prowincji albo przez biskupów sąsiedniej prowincji biskup, ma prawo odnieść się do biskupa Rzymu. Gdyby przez zwołany na zlecenie Rzymu synod sąsied-

9 Por. Joannou, Die Ostkirche, dz. cyt., s. 83-87; K. Baus, E. Ewig, Die Kirche von Nikaia bis Chalkedon (= HKG (J) 2/1, Freiburg, Basel, Wien 1973, s. 38-42. K. Schatz, Primat, dz. cyt., s. $39-41$. 
niej prowincji ponownie go potępił, ale Rzym nie potwierdziłby tej decyzji, wówczas, zgodnie z 4 . kanonem synodu w Sardyce, mógłby taki biskup sam złożyć zażalenie u biskupa Rzymu. Jego potępienie pozostaje wówczas tak długo zawieszone, aż biskup Rzymu, na prośbę potępionego, nie zleci synodowi sąsiedniej prowincji, zgodnie z 5. kanonem Synodu Sardyjskiego, ostatecznego wyjaśnienia danego przypadku. Przy tym, na życzenie potępionego, biskup Rzymu mógłby wysłać kilku rzymskim prezbiterów, aby wzięli udział w podjęciu ostatecznej decyzji.

Kanony z Sardyki opisują więc biskupa rzymskiego nie jako instancję apelacyjną, ale jako instancję rewizyjną. Przyznają one wprawdzie biskupowi Rzymu pewne prawa do potwierdzania czy podejmowania decyzji, jednak już niejako na przedpolu są stale włączane synody względnie niektórzy ojcowie synodalni, bez których udziału decyzje rzymskie byłyby nie do pomyślenia. Biskup Rzymu jest więc według synodu w Sardyce jeszcze włączony do podejmowania decyzji w synodalnej konstytucji kościelnej późnej starożytności. Godne uwagi jest też uzasadnienie, jaką rolę przypisuje biskupowi Rzymu jeden z ojców synodalnych Ossius z Kordoby: „Chcemy uczcić pamięć św. Apostoła Piotra.” W tym uwidacznia się bardzo wyraźnie stan kościelnej świadomości: ponieważ Kościół rzymski jest Kościołem Piotra i stąd posiada szczególny autorytet, jest więc predestynowany do tego, aby podejmować decyzje co do nowych praw w rozwiązywaniu aktualnych konfliktów kościelnych. Na Zachodzie, poczynając od V wieku, wchodzi w życie proces, pod wpływem tego kanonu, który nada Rzymowi, najpóźniej około roku 1200 za papieża Innocentego III, wyłączną kompetencję we wszystkich przypadkach, które będą dotyczyły tak biskupów jak i biskupstw (causae maiores).

\section{Rzym jako miejsce ucieczki biskupów Wschodu w ich trudnych sytuacjach ${ }^{10}$}

Na Wschodzie Rzym umacnia swój autorytet, może powolne, ale poprzez systematyczne zaangażowanie swoich biskupów w sprawę wyznawania wiary w Chrystusa zgodnie z postanowieniami Soboru Nicejskiego. Około roku 370 przezwyciężają wprawdzie biskupi kapadoccy teologicznie panujący jeszcze na Wschodzie arianizm, jednak communio pomiędzy lokalnymi Kościołami Wschodu w dalszym ciągu jest nadwerężona albo całkowicie zerwana, a także często w poszczególnych Kościołach panują podziały i rozdarcia. Rzym wykazuje się natomiast większą stałością, stabilnością i klarownością. Ten pocieszający stan Kościoła rzymskiego podsuwa lokalnym Kościołom wschodnim szukanie komunii ze stabilnym Kościołem rzymskim, która zawiera w sobie także wspólnotę z całym łacińskim Zachodem. W ten sposób przypada Kościołowi

10 Por. K. Schatz, Primat, dz. cyt., s. 41-43. 
Rzymu coraz bardziej rola centrum, o które warto zabiegać i od którego można oczekiwać pośrednictwa dla kościelnej jedności na Wschodzie.

W starej, ale już myślącej i mówiącej po łacinie stolicy Cesarstwa Rzymskiego, często nie dysponuje się już fachowymi kompetencjami trudnych problemów wschodniej teologii formułowanej po grecku. Dalej, na Zachodzie nie zawsze jest się wystarczająco poinformowanym o sytuacji lokalnych Kościołów na wschodzie Cesarstwa. Ponadto brakuje często Kościołowi rzymskiemu możliwości do wprowadzenia zarządzeń i decyzji przewidzianych dla Kościołów wschodnich. Oto np. Bazyli z Cezarei († 379) stwierdza zawiedziony, że Kościół Rzymski zbyt pospiesznie wystawia listy wspólnotowe do biskupów, którzy między sobą zerwali communio. Przede wszystkim skarży się Bazyli na wyniosłe i aroganckie zachowanie biskupa Rzymu Damazego († 384). W rzeczywistości Damazy posługuje się w kontaktach z Kościołami wschodnimi wyniosłym tonem, który E. Caspar określa jako „dyktat a nie dyskusja” ${ }^{11}$. Takim stylem przeforsował Damazy wobec 153 biskupów obradujących na synodzie w Antiochii w 379 roku swój Tomus, zawierający zbiór rzymskich sformułowań wiary, bez dyskusji i innych postanowień do podpisania i to tak, że podyktowane warunki communio zostały przyjęte ${ }^{12}$.

Biskupi rzymscy nie zawsze zdołali ustalać tak jednostronnie warunków komunii. Pomimo tego jedność z Rzymem zdobywała w zagrożonych Kościołach wschodnich coraz większe znaczenie. Tak też wydany przez cesarza edykt Cunctos Populos nie przynosi na Wschodzie oczekiwanego efektu, który podnosi katolickie chrześcijaństwo do statusu religii państwowej, a jednocześnie podnosi znaczenie Rzymu. Obywatele Cesarstwa powinni, zgodnie z tym edyktem w znaczeniu religijnym, ukierunkowywać swoją reprezentowaną przez biskupów Rzymu Damazego i Aleksandrii Piotra wiarę. Ale nie można nie dostrzec, że edykt ten wskazuje na początek tej wiary w Piotrze, względnie na wiarę głoszoną przez niego w Rzymie. Mimo równorzędnego potraktowania wiary biskupów Rzymu i Aleksandrii zauważa się wyraźnie wyższe dowartościowanie Rzymu.

W następstwie takiej sytuacji od IV wieku coraz częściej zwracają się wschodni chrześcijanie w trudnych momentach do Rzymu, ufając, że stamtąd otrzymają energiczną pomoc i skuteczne wsparcie. Przekonanie to będzie silniejsze w sytuacjach, gdy biskupi będą usunięci z ich stolic albo będą forsowane fałszywe nauki przez cesarzy. Wówczas oczekuje się od Rzymu aktów solidarności, upomnień przeciwników, pism do biskupów i inicjatyw na soborach. Nie przekracza oczywiście to zaufanie poziomu wysokiego autorytetu i będzie niekiedy nawet relatywizowane. Dochodzi coraz częściej do tego, że woła się o pomoc nie tylko Kościół w Rzymie, ale i inne znaczące stolice biskupie.

$11 \quad$ E. Caspar, Geschichte, dz. cyt., s. 227.

12 Co do Tomus Damazego por. Joannou, Die Ostkirche, s. 15 i n. oraz s. 218-222. 
Jednak biskup Flawian szuka ochrony wyłącznie u papieża Leona, kiedy on w 449 roku zostanie usunięty na tzw. synodzie zbójeckim ${ }^{13}$. Prosi on biskupa Rzymu, aby zechciał napisać do cesarza, do kleru i do ludu Bożego Konstantynopola jak też do tych biskupów, którzy go pod presją potępili. Ponadto postuluje, by ten zwołał na Wschodzie i na Zachodzie synody, aby zachować nienaruszoną wiarę i aby anulować potępienia "zbójeckiego synodu”.

Odwołanie się do wyższej instancji jest właściwie wołaniem o pomoc, z jaką zwraca się w 449 roku Teodoret z Cyru do papieża Leona po potępieniu go przez „zbójecki synod”. Pisze on, że nie pozwolono mu udać się na synod na podstawie cesarskiego rozkazu. Dlatego odwołuje się on do autorytetu Stolicy Apostolskiej i oczekuje od niej właściwego wyroku. Teodoret dodaje, w sensie pewnej captatio benevolentiae, że sława Rzymu, pomijając jego polityczną rangę, polega przede wszystkim na jego wierze, która jest „,w całym świecie sławna” (Rz $1,8)$. Ponadto dochodzi do tego posiadanie grobów Apostołów Piotra i Pawła, którzy jak słońce wschodzi na Wschodzie, a na Zachodzie zachodzi, a przy tym dzisiaj stamtąd oświeca cały świat poprzez stolicę biskupa rzymskiego.

Reasumując można powiedzieć, że stare główne Kościoły: Rzymu, Aleksandrii i Antiochii rozwijają się do regionalnych centrów komunii pod koniec trzeciej fazy rozwoju ${ }^{14}$ pod wpływem „konstantyńskiego przełomu”, które są wyposażone i państwowo i ze strony kościelnej usankcjonowaną, przekraczającą granice metropolii jurysdykcję. Jerozolima rozwija się w tym kierunku tylko szczątkowo. Pod koniec IV wieku Kościół na Wschodzie coraz bardziej przyłącza się do stolicy Cesarstwa Konstantynopola. Rzym, cieszący się wielkim uznaniem i wyjątkową stabilnością, przewyższa także w IV wieku inne główne Kościoły i staje się powoli ponadregionalnym centrum communio, od którego oczekuje się tak na Wschodzie jak i na Zachodzie pomocy w trudnych sytuacjach. Ten czas wyróżnia się jednocześnie przejściem do czwartego stopnia rozwoju, w którym kształtowanie się rzymskiego prymatu i patriarchatu Cesarstwa daje się bardzo dokładnie zauważyć.

\section{Czwarty stopień: ukształtowanie się rzymskiego prymatu i patriarchatu Cesarstwa od końca IV wieku do Soboru w Chalcedonie (451)}

W czasie czwartego stopnia rozwoju kształtuje się idea rzymskiego prymatu od początku IV wieku przede wszystkim w zachodniej części starożytnego chrześcijaństwa, podczas gdy na greckim Wschodzie tylko w małym stopniu

13 Co do wołania Flawiana i Teodoreta proszących o pomoc papieża Leona por. E. Caspar, Geschichte, dz. cyt., s. 489-492.

14 O stopniach rozwoju znaczenia starodawnych stolic biskupich zob. tegoż autora (J. Hofman), Znaczenie wspólnot chrześcijańskich i ich biskupa dla całego Kościoła w pierwszych trzech wiekach chrześcijaństwa, Rocznik Teologii Katolickiej, T. VII (2008), s. 272-290. 
widoczna jest jego dynamika. Nowe czasy dają znać o sobie już w tytule papieża, który teraz wyłącznie jest zastrzeżony biskupom Rzymu i Aleksandrii ${ }^{15}$. Greckim słowem papas, jako poufałe zwracanie się do ojca, będą w starożytnych czasach nazywane te osoby, którym przypisywano wysoki autorytet duchowy, a więc biskupi, opaci i prezbiterzy. Zlatynizowana forma papa pojawia się od III wieku na Zachodzie jako honorowy tytuł biskupa. Odpowiednio do rosnącego znaczenia biskupów Rzymu i Aleksandrii zwracano się od połowy V wieku do biskupów Rzymu i Aleksandrii, zasiadających na obu tych stolicach, już prawie wyłącznie tym honorowym tytułem papa. Jednak najpierw przypisywano ten tytuł „papieża” biskupowi Rzymu i oznaczał on wielki duchowy autorytet, którym się on cieszył ze strony innych.

To zewnętrzne przypisywanie tytułu „papieża” biskupowi Rzymu idzie w parze z dalszym rozwojem idei prymatu, do której zwracają się przede wszystkim papieże Damazy († 384), Siricius ( $† 399)$, Innocenty I ( $†$ 417) i Leon Wielki $(\dagger 461)^{16}$. Biorąc pod uwagę szczególną godność Kościoła rzymskiego, która przysługuje mu dzięki znajdującym się tam grobom Apostołów Piotra i Pawła, jest teraz rozwijany cały powiązany $\mathrm{z}$ tym kompleks idei, rozbudowuje się ją z myślą o następcach Piotra na stolicy rzymskiej. Chociaż Stefan, biskup Rzymu, odwołuje się w połowie III wieku także do następstwa Piotrowego biskupów Rzymu, to jednak ten motyw staje się teraz ideą wiodącą, czymś jednoznacznym w rozumienia papiestwa. W papieżu jest obecny sam Piotr; w papieżu żyje on dalej. Dla Leona Wielkiego papież jest w sensie prawa rzymskiego ponadto „dziedzictwem Piotra” i stąd jedynym prawowitym posiadaczem władzy kluczy. Zgodnie $\mathrm{z}$ innym centralnym pojęciem, które utrzymuje się aż do końca pierwszego tysiąclecia, widzi Leon w papieżu „zastępcę Piotra”, tak jak Piotr dla niego jest następcą Chrystusa. Ponadto w Rzymie aż do początku drugiego tysiąclecia powołuje się na obu koryfeuszy Piotra i Pawła, którzy jako para, uzasadniają wielkie znaczenie chrześcijańskiego Rzymu, można tak powiedzieć niejako w przeciwieństwie do legendarnych założycieli miasta Romulusa i Remusa.

Jakie zadania i wymagania na gruncie tej identyfikacji łączą papieże ze swoim urzędem? Na pierwszym miejscu należy wymienić ich „troskę o wszystkie Kościoły (sollicitudo omnium ecclesiarum)". Papież Innocenty I ( $†$ 417) wyraża w tym sformułowaniu, cytując św. Pawła (por. 2 Kor 11, 28), ponadregionalny obowiązek troski rzymskich biskupów, a co dla synodów innych Kościołów

15 Co do tytułu „papież” por. Das Lemma Papstum, [w:] G. Denzler, C. Andresen, dtvWörterbuch der Kirchen-geschichte, München 1993 wyd. 3-e, s. 452-454, tu: 452. Wcześniejsze dowody na tytuł „papież“ odnośnie do biskupów Rzymu i Aleksandrii zob. pod Lemma (papas, pappas) u G. W. H. Lampe, A Patristic Greek Lexikon, Oxford 1961, 1008 A 1 b i c.

16 Dalszemu rozwojowi idei rzymskiego prymatu na Zachodzie poczynając od IV wieku por. W. de Vries, Das Petrusamt im ersten Jahrtausend, [w:] K. Lehmann (red.), Das Petrusamt. Geschichtliche Stationen seines Verständnisses und gegenwärtige Positionen, München, Zürich 1982, s. 42-66; tu: s. 51-53; K. Schatz, Primat, dz. cyt., s. 44-46. 
ma to takie konsekwencje, że wszystkie rozpatrywane przypadki „o doniosłym znaczeniu (causae maiores)" należy przedłożyć Rzymowi do oceny. Do tego dochodzi jeszcze wypowiedziane przez papieża Bonifacego I ( $† 422)$ wyobrażenie o Kościele rzymskim jako głowie (caput) Kościoła katolickiego, któremu inne lokalne Kościoły są podporządkowane jako członkowie. Stąd legaci papieża Leona Wielkiego już w roku 451 określają go jako „biskupa wszystkich Kościołów”. Jest dlatego konsekwentne, że papież Leon domaga się „pełni jurysdykcyjnej i nauczycielskiej władzy (plenitudo potestatis)" nad całym Kościołem, powołując się przede wszystkim na Mt 16, 18 nn. Kształtuje się odtąd w Rzymie coraz silniejsze przekonanie, że podejmowane przez Kościół rzymski decyzje odnośnie do Kościołów lokalnych mają znaczenie obowiązujące.

Ten obraz Kościoła ukierunkowany na Rzym określa także od końca IV wieku i działanie biskupów rzymskich. Ważnym krokiem milowym na tej drodze jest pierwsze „papieskie zarządzenie (Decretale)”. Chodzi o pisemną odpowiedź z roku 385, którą papież Syrycjusz doręcza hiszpańskiemu biskupowi Himeriuszowi z Tarragony na jego pytanie, a przez niego poleca przekazać tę odpowiedź wszystkim biskupom hiszpańskim. W odróżnieniu od wcześniejszych rzymskich listów, nie ma już tu braterskiego tonu czy usilnego upomnienia. Zarządzenie Syrycjusza odznacza się raczej tonem rozkazującym jakby urzędowego nakazu cesarskiego. Łatwe do zauważenia są wysokie wymagania nadawcy. Himeriusz zwrócił się w swoim pytaniu do „Głowy (kościelnego) Ciała”. Stąd nie może zarządzenie Stolicy Apostolskiej, jak w tym przypadku, być zignorowane przez żadnego biskupa. Jest on przecież obecny w papieżu Piotrze, „ten, jak ufamy, swoje dziedzictwo we wszystkim chroni i zachowuje" (jak pisze papież Syrycjusz we wstępie do listu skierowanego do biskupa Himeriusza $\mathrm{z}$ Tarragony). Nowością jest także i to, że papież Syrycjusz niejako jednym tchem mówi o „kanonach (synodów) i o (papieskich) konstytucjach zarządzających” albo o „statutach Stolicy Apostolskiej i o godnych szacunku decyzjach synodalny$\mathrm{ch}^{17}$. Dotychczas synody mogły ustanawiać tylko nowe prawo kościelne. Odtąd także papieskie pisma będą podniesione do poziomu obowiązującego prawa synodalnego. Oczywiście, poprzez całe wieki papieskie zarządzenia zawierają treściowo obowiązujące prawo kościelne, a dokładniej mówiąc, papieże dają odpowiedź Kościołom lokalnym jako świadkowie uprzywilejowanej tradycji i w spornych problemach dzielą się z nimi stanowiskiem reprezentowanym przez Kościół rzymski.

17 Por. E. Caspar, Geschichte, dz. cyt., s. 262. 


\section{Duchowo-ideologiczne zaplecze: Roma christiana jest spadkobiercą Roma aeterna ${ }^{18}$}

Opisane kształtowanie się papieskiego prymatu byłoby trudne do wyobrażenia bez integracji Kościoła w Cesarstwie Rzymskim. Oto pod koniec IV wieku sami członkowie starego rzymskiego Senatu przyjmują wiarę chrześcijańską, co sprawia, że podstawowe społeczne i ideologiczne struktury starożytnego miasta cesarskiego przetrwają i wchodzą w niepodważalną symbiozę z chrześcijaństwem. Arystokratyczny senat miasta Rzymu będzie odtąd dostarczać kandydatów na biskupów Rzymu i jego najbliższych współpracowników, ale też będzie wnosić do Kościoła rzymskiego swoje typowe struktury myślowe i zdolności. Przede wszystkim swoje prawo i porządek, swój charyzmat kierownictwa i równowagę $\mathrm{w}$ przeciwieństwach, swoje trzeźwe podejście do praktyki, ale także poczucie sensu we władzy, krótko mówiąc, to wszystko, co dotychczas umożliwiło Rzymowi posiąść władzę nad ówczesnym światem, przypada teraz Kościołowi rzymskiemu w dziedzictwo ze wszystkimi jasnymi i ciemnymi stronami.

$\mathrm{Na}$ tym podłożu staje się jasne, dlaczego teraz Kościół rzymski przyjmuje wszystko, co w prawodawstwie i w prawie da się przełożyć na życie Kościoła. „Piotr prawodawca” (Petrus legislator) wyciska odtąd na Kościele rzymskim wiodący obraz, który w sztuce wyraża się owym „przekazaniem prawa” (traditio legis). Na przykładzie motywu, który znajduje się na rzymskim sarkofagu z około 370 roku, widać bardzo dobrze na środku postać Jezusa Chrystusa. $\mathrm{Na}$ wzór starotestamentalnego wydarzenia z góry Synaj, Chrystus przekazuje Apostołowi Piotrowi, stojącemu po Jego prawej stronie, zwój księgi. Chodzi tu o nowotestamentalne „prawo wiary (lex fidei)”, które św. Piotr ma dalej przekazywać nowemu Ludowi Bożemu Kościoła. Piotr więc jest tutaj przedstawiony jako Nowy Mojżesz. Ma to wyrażać: tak jak Mojżesz przekazał Ludowi Bożemu Starego Testamentu Boże Prawo, tak teraz św. Piotr przekazuje narodom tablice prawa Nowego Testamentu. Jeżeli powiąże się te rozważania ze zdobywającym coraz bardziej uznanie wyobrażeniem papieża jako dalej żyjącego Piotra i jako dziedzica Piotrowej władzy, to znaczy, że teraz przypada mu zadanie przekazywać swoim współczesnym w sposób zobowiązujący prawo Nowego Testamentu i w ten sposób realizować „pełnię władzy kierowniczej dla całego Kościoła (plenitudo potestatis)".

W taki to sposób dokonuje się nowe zaakcentowanie rzymskiego prymatu, który wyciśnie znacząco nowe oblicze na zachodnim Kościele. Starożytny czcigodny Kościół rzymski, wielce szacowny Kościół niezafałszowanej apostolskiej tradycji, przejmuje bowiem rolę Kościoła stolicy Cesarstwa, który - stojąc pod wpływem imperialnej mentalności swego otoczenia - przekazuje narodom

18 Por. K. Schatz, Primat, dz. cyt., s. 46 n. 
Cesarstwa swoje prawa i rozporządzenia. Roma christiana staje się Kościołem, który swoje zadania widzi odtąd również w tym, aby innym Kościołom lokalnym, a także regionalnym synodom przekazywać $\mathrm{w}$ razie potrzeby zarządzenia i nakazy.

Wobec Kościołów wschodnich zachowuje się Rzym zasadniczo bardziej powściągliwie. Sam papież Leon Wielki nie pisze do nich w stylu rozkazującym. W stosunku do tych Kościołów rozumieją się papieże raczej jako „czuwający nad kanonami soborowymi (custodes canonum)”. Ze strony rzymskiej przejmuje się tutaj przede wszystkim odpowiedzialność za zachowanie tradycji, przeciwko stale zmieniającym się sformułowaniom prawd wiary, które co i raz wywracają tradycję oraz angażuje się w przestrzeganie postanowień soborowych, podkreślając ich ponadczasowe znaczenie.

Ale co rozumie się pod nazwą „sobór ekumeniczny”? Chodzi tu o zwołanie biskupów całego Cesarstwa, którzy podejmują decyzje w spornych sprawach, a które będą miały moc wiążącą dla całego Kościoła, a zwłaszcza dla Kościołów Cesarstwa Rzymskiego. Papieże późnej starożytności czują się stróżami tych postanowień soborowych i zobowiązani wymagać ich wypełnienia ze strony Kościołów całego Cesarstwa w rozumieniu ekumenicznym. Jest jasne, że obraz stosunku Kościoła rzymskiego do soborów ekumenicznych będzie zróżnicowany.

\section{Stosunek Rzymu do trzech pierwszych soborów ekumenicznych (325-451)}

Na pierwszym soborze ekumenicznym, który miał miejsce w Nicei w 325 roku biskup rzymski nie odgrywał właściwie żadnej roli. Pomimo tego są trzej zachodni ojcowie soborowi bardzo ściśle związani z Rzymem. Jako pierwszego należy wymienić biskupa Ozjusza z Kordoby, wyróżniającego się biskupa na tym soborze, któremu bardzo prawdopodobnie przypadło $\mathrm{w}$ udziale zadanie reprezentowania, będącego już w podeszłym wieku, papieża Sylwestra ${ }^{19}$. Do niego dołączają się dwaj rzymscy prezbiterzy Vitus i Vincentius. Wszystkich ich, wydaje się mieć papież Damazy przed oczyma, gdy wobec wschodnich biskupów podkreśla, że prawdy wiary sformułowane w Nicei są przede wszystkim dlatego do przyjęcia, ponieważ tam byli ojcowie soborowi, „którzy reprezentowali Jego Świątobliwość biskupa Rzymu"20. Obecność i akceptacja Rzymu są Damazemu

19 Por. tu i w dalszych rozważaniach I. Ortiz de Urbina, Nizäa und Konstantinopel (= GÖK - Geschichte der ökumenischen Konzilien 1) Mainz 1964, s. 62.

20 Damazy, Ep. Confidimus quidem u Joannou, Die Ostkirche, dz. cyt., s. 162 n. nr 54, tu: s. 162. Według Joannou (tamże) chodzi o list synodalny papieża Damazego napisany po rzymskim synodzie z 368 roku, którego kopię papież przesłał także w 372 roku do wschodnich biskupów; por. tu i dalej H. J. Sieben, Die Konzilidee der Alten Kirche (= KonzGe, Seria B: Untersuchungen) Paderborn, München, Wien, Zürich 1979, s. 229 i n. 
decydujące dla zachowania autorytetu soboru. $Z$ drugiej strony Damazy nie uznaje soboru, który miał miejsce w Rimini także dlatego, ponieważ nie brała w nim udziału Stolica Apostolska. W surowym prawniczym języku oznacza to, że dopiero współdziałanie Stolicy Apostolskiej nadaje prawomocność danemu soborowi.

To przekonanie odpowiada także już w wyjaśnianej decyzji regionalnego Synodu Rzymskiego z roku 382, który odrzuca podniesienie Konstantynopola na soborze ekumenicznym z 381 roku do rangi drugiego głównego Kościoła Cesarstwa Rzymskiego, ponieważ Rzym nie był reprezentowany na tym soborze i że pierwsze miejsce zawdzięcza Kościół rzymski nie decyzjom soborowym, lecz opiera się na słowie Pana skierowanym do św. Piotra. Podobnie wstawia się Kościół rzymski za innymi głównymi Kościołami: aleksandryjskim i antiocheńskim, ponieważ także one zgodnie $\mathrm{z}$ tradycją jako trzy stolice biskupie związane są ze św. Piotrem, stąd też im należy się po Rzymie godność drugiej i trzeciej stolicy.

Podobną linię reprezentuje Rzym na trzecim soborze ekumenicznym, który miał miejsce w Efezie w 431 roku $^{21}$. Tu podkreśla rzymski prezbiter Filip miarodajność Rzymu, gdy dziękował zebranym tam biskupom przede wszystkim za ich zgodność z biskupem Rzymu. Jeszcze dokładniej wyraża się biskup Projectus, przewodniczący delegacji rzymskiej na soborze, gdy on, w typowo urzędowym stylu rzymskim, podpisywał potępienie Nestoriusza: „[Biskup Projectus] zarządza mocą swego autorytetu, że Nestoriusz zostaje potępiony" (Akta soboru z dnia 11 lipca 431 roku). Natomiast prezbiter Filip niejako $\mathrm{w}$ formie interpretacji dodaje: „Nikt nie wątpi, ponieważ jest to znane od najdawniejszych czasów, że święty Apostoł Piotr, książę i głowa Apostołów, kolumna wiary i fundament Kościoła katolickiego, klucze królestwa otrzymał od naszego Pana Jezusa Chrystusa, Zbawiciela i wybawcy rodu ludzkiego. I On żyje i sądzi aż do obecnego czasu i tak będzie zawsze w Jego następcach" (Akta soboru z 11 lipca 431 roku). Decydujące dla ważności synodalnych dekretów jest więc - według wyostrzonego sensu cytowanych wypowiedzi - sądownicza władza biskupa Rzymu.

Zupełnie inaczej ocenia rolę biskupa Rzymu biskup Dioskur z Aleksandrii na synodzie w Efezie z 449 roku, tzw. „synodzie zbójeckim”22. Dioskur jako przewodniczący soboru zrywa tradycyjną więź pomiędzy Rzymem i Aleksandrią i nie pozwala rzymskim legatom odczytać przywiezionego na synod listu papieża Leona, sławnego Tomus Leonis. Co więcej, idzie jeszcze dalej i ekskomunikuje papieża Leona. Gdy sprzeciw staje się głośny, a prezbiter Hilary, rzymski legat papieża, odrzuca te postanowienia, Dioskur każe otworzyć drzwi

21 Por. P.-Th. Camelot, Ephesus und Chalcedon (=GÖK 2), Mainz 1963, 62 i n.

22 Co do „rozbójniczego synodu” i soboru w Chalcedonie zob. K. Schatz, Primat, dz. cyt., s. 59-64. 
kościoła, w którym odbywał się synod, i wkraczają do niego żołnierze i rozwrzeszczana tłuszcza - stąd nazwa „synod zbójecki” - aby złamać opór ojców synodalnych.

I tutaj po raz pierwszy rodzi się pytanie, jaki powinien zaistnieć stosunek pomiędzy ekumenicznym soborem a rzymskim biskupem. Przecież „zbójecki synod" z 449 roku obradował nie tylko bez przedstawicieli Rzymu, ale także zwołany przeciwko Rzymowi. Problem polega na tym, że na tym nieudanym synodzie zderzyły się ze sobą dwie przeciwstawne zasady. Dioskur reprezentował formułę: „Tylko Nicea” - bardzo tradycjonalistyczną zasadę, która uważa za ważne wyznanie wiary tylko te z przed stu laty soboru Nicejskiego. Tej zasadzie stara się pozostać wierny również papież Leon Wielki ze swoim Tomus Leonis, ale próbuje też z całą otwartością odpowiadać na aktualne problemy wiary we współczesności. W 449 roku osiąga Dioskur - biskup aleksandryjski - protegowany przez cesarza Teodozjusza II ze swoją tradycjonalistyczną zasadą krótkotrwałe zwycięstwo. Ale nowy cesarz Markian umożliwia już w 451 roku zwołanie nowego soboru w Chalcedonie ze zdecydowanym współudziałem Rzymu.

\section{Za i przeciw Kościoła rzymskiego i cesarskich patriarchatów na ekumenicznym soborze w Chalcedonie}

Na tym soborze legat Rzymu Lucencjusz wnosi zaraz na początku skargę przeciwko Dioskurowi. Przestępstwo biskupa z Aleksandrii polega na tym, że „odważył się przeprowadzić sobór pomijając autorytet Stolicy Apostolskiej, co się dotąd nie wydarzyło, ani nie może się więcej wydarzyć" (Lucencjusz zanotowany w protokole Soboru z 451 roku). Rzymskiemu legatowi nie chodziło o zwołanie soboru za zgodą Rzymu, który odbywałby się po przysłaniu przez Rzym swoich legatów. Lucencjusz zwraca się przeciw świadomemu przeszkodzeniu odczytania rzymskiego listu pouczającego. Bardzo ważne jest, że także ojcowie soborowi wzięli czynny udział w potępieniu papieża przez Dioskura, który „szczekał na Stolicę Apostolską" i próbował ekskomunikować papieża Leona (por. Pismo ojców soborowych z 451 roku do cesarza Markiana).

Ojcowie soborowi, którzy teraz mogą słuchać listu papieża Leona, odrzuconego przez Dioskura, i nad nim dyskutować na plenum, oceniają go z najwyższym uznaniem. Sławnymi aklamacjami: „Piotr przemówił przez Leona” albo „to jest nasza wiara”, albo "Leon i Cyryl nauczają tego samego", pragną wyrazić, jak bardzo zgadzają się z nauczaniem Leona. Według ich przekonania Piotr ponownie przemówił przez Leona dając znaczące świadectwo Jezusowi Chrystusowi, udowadniając, że jest ową obiecaną skałą. Jasne, że u niektórych ojców soborowych widoczne były pewne trudności w zaakceptowaniu takiego stanowiska.

W jaki sposób wyraża się ta świadomość autorytetu u papieża Leona? Nie obstaje on przy bezdyskusyjnym przyjęciu jego listu i akceptuje debatę ojców 
nad nim, aby porównać go z tradycją Ojców Kościoła. Ale oczywiste jest, że nie przyjmuje jego odrzucenia. Leon jest bowiem przekonany, że „przewodniczy on Kościołowi w imieniu kogoś, którego wyznanie było pochwalone przez samego Pana Jezusa i którego wiara zniszczy wszystkie herezje, a przede wszystkim zwalcza bezbożność obecnego błędu"23.

Chociaż ojcowie soborowi wysoko oceniają nauczanie Leona, w większości przeciwstawiają się czemuś nowemu, dotyczącemu także samego Leona, tzn. wykraczania poza definicję wiary soboru nicejskiego. Rzymscy legaci zdołają przezwyciężyć ten opór, gdy - w przypadku obstawania przy dogmatycznym status quo - grożą opuszczeniem soboru i kontynuowaniem go w Italii. W ten sposób dochodzi do autorytatywnego włączenia się papieża Leona do sformułowania zaktualizowanej definicji wiary. Jedynie dzięki papieżowi i jego legatom tak pewnie wykonywany urząd Piotrowy daje się przezwyciężyć zbyt tradycjonalistyczną zasadą z Chalcedonu. Tę kluczową funkcję zdoła Rzym pełnić tak owocnie zresztą tylko dlatego, ponieważ ojcowie soborowi identyfikują nauczanie papieża Leona $\mathrm{z}$ kerygmą św. Piotra.

W jednym punkcie kościelnych ustaw z Chalcedonu wprowadza się zasadę dla całego Cesarstwa jako zwycięską nad Piotrową zasadą Rzymu. Prawdopodobnie 29 października 451 roku obradowano pod nieobecność rzymskich legatów nad przywilejami stolicy biskupiej w Konstantynopolu ${ }^{24}$. Uchwalono przy tym dekret (kan. 28), który stanowi, że Konstantynopolowi, ze względu na polityczną rangę miasta cesarskiego, przyznaje się drugie miejsce po Rzymie i przyznaje się mu godność równą Rzymowi. Ponadto Konstantynopol otrzymuje diecezje Pontu, Azji i Tracji jako należące do jurysdykcji biskupa Konstantynopola i prawo wyświęcania tamtejszego metropolity. Na sprzeciw rzymskich legatów dekret został na kolejnym posiedzeniu ponownie przedyskutowany. Diakon Aecjusz z Konstantynopola odpowiedział legatom, że byli oni o wszystkim poinformowani, dlatego traktowano tę sprawę zgodnie ze zwyczajem synodalnym. Legaci jednak odsunęli się od dalszego prowadzenia soboru wyjaśniając, że nie otrzymali w tym względzie żadnych instrukcji. Nastąpiło odczytanie dekretu i składania podpisów, którego unieważnienia domagał się Lucencjusz. Zebrani jednak zapewnili, że głosowali w sposób wolny. Na to rzymscy legaci przedstawili prawne podstawy swojego sprzeciwu, cytując kanon 6. Soboru z Nicei, podczas gdy druga strona wskazała na kanony z Konstantynopola. Ostatecznie biskupi Azji i Pontu wyjaśniają ich zgodę na dekret, ponieważ, według nich, sankcjonuje on istniejącą już praktykę. Tak więc ten dekret, pomimo oporu rzymskich legatów, został zatwierdzony. Ponieważ zgromadzenie liczyło się $\mathrm{z}$ dalszymi zarzutami ze strony Rzymu, poinformowano papieża Leona o wy-

23 Papież Leon, List 61, 2 cyt. H. J. Sieben, Die Konzilidee, dz. cyt., s. 123.

24 Co do tego soborowego dekretu por. P.-Th. Camelot, Ephesus und Chalcedon, dz. cyt., s. 182-185 i L. Perrone, Von Nicaea, dz. cyt., s. 116. n. 
nikach dyskusji na tematy dogmatyczne, jak o tej decyzji soboru (wyróżnienia Konstantynopola) i podkreślono jego zgodność z tradycją.

Papież Leon odrzucił jednak ten dekret i przeciwstawił polityczno-kościelnej zasadzie Cesarstwa - zasadę apostolską i Piotrową. Nie polityczne znaczenie, ale jego apostolskie założenie może decydować o kościelnej randze danego miasta. Przecież Rzym opiera swoją kościelną godność na Apostołach Piotrze i Pawle, a nie na randze stolicy Cesarstwa. Także druga i trzecia $w$ rankingu stolice biskupie czerpią swą godność tylko i wyłącznie na zawsze $\mathrm{z}$ ich apostolskiego założenia: po Rzymie idzie Aleksandria, a po Aleksandrii Antiochia. Leon odwołał się przy tym do niepodważalnego kanonu 6. Soboru w Nicei i oparł się także na, po raz pierwszy wspomnianej w roku 382, teorii o trzech stolicach Piotrowych. W Kościele starożytnym nie zdobyły większego znaczenia ani zasada Apostolsko-Piotrowa, ani też polityczno-cesarska a zarazem kościelna. Na Wschodzie decydowała raczej zasada polityczno-cesarska, na Zachodzie zaś Apostolsko-Piotrowa, które będą wpływać na dalszy przebieg historii Kościoła.

\section{Spojrzenie wstecz i perspektywy}

Spoglądamy teraz wstecz: do soboru w Chalcedonie pojawiają się, obok Kościoła rzymskiego, trzy inne wschodnie Kościoły główne. Starożytne Kościoły główne: Rzym, Aleksandria i Antiochia ukazują się, pod wpływem „konstantyńskiego przełomu" już od soboru w Nicei od 325 roku, jako Kościoły regionalne wyposażone w prawną państwowo-kościelną jurysdykcję i stają się centrami komunii. Ponadto Aleksandrii zostało przyznane w Nicei, a Antiochii w Konstantynopolu w 381 roku, że uzyskują one ponadmetropolitalną jurysdykcję. Kanon 3. soboru w Konstantynopolu z 381 roku nadaje także nowej wschodniej stolicy Cesarstwa, Konstantynopolowi, tytuł Kościoła głównego z polityczno-kościelnym uzasadnieniem, pomimo protestów ze strony Rzymu i Aleksandrii. Ponadprowincjonalne prawo jurysdykcji Konstantynopola zostało dokładnie ustalone, pomimo oporu Rzymu, dopiero na soborze w Chalcedonie (kan. 28). Ale także w Nicei wyposażeni godnością prymatu biskupi jerozolimscy doznali szczególnego wyróżnienia ${ }^{25}$. Biskup Juwenal z Jerozolimy posiadał znaczny autorytet w Palestynie, gdy przewodniczył na soborze w 431 roku delegacji około piętnastu biskupów palestyńskich. Jednak sobór odmówił mu ponadmetropolitalnej jurysdykcji nad tymi biskupami. Ten cel osiągnął Juwenal na soborze w Chalcedonie, gdy 26 października 451 roku, dzięki poparciu

25 Co do żądań biskupów Cyryla i Juwenala z Jerozolimy por. E. Camelot, Ephesus und Chalcedon, dz. cyt., s. 170 i n. (Patriarchatssprengel von Jerusalem); L. Perrone, Von Nicaea, dz. cyt., s. 91 i 95 (Juvenal von Jerusalem auf dem Konzil von Ephesus), s. 111 i 115 (Juvenal auf dem Konzil von Chalcedon); F. R. Gahbauer, Die Pentarchietheorie. Ein Modell der Kirchenleitung von den Anfängen bis zur Gegenwart (FTS 42), Frankfurt am M. 1993, s. 46; G. Röwekamp, Cyrill von Jerusalem, W; LACL, wyd. 3, s. 178-180; tu: 178 i n.; Tenże, Juvenal von Jerusalem, [w:] LACL, s. 416 i n. 
legatów rzymskich, została przekazana mu ponadmetropolitalna jurysdykcja nad trzema prowincjami Palestyny ${ }^{26}$. Wprawdzie potem powstał opór ze strony papieża Leona jak i biskupa Maksimusa z Antiochii, (por. zwłaszcza list 119, 4 papieża Leona do Maksimusa $\mathrm{z}$ Antiochii), ale i oni nie mogli już zmienić decyzji soboru w Chalcedonie.

Rzym nie zaakceptował także podniesienia do wyższej rangi Konstantynopola i dał wyraźnie do zrozumienia, że według przekonania [Rzymian] postanowienia soborowe osiągają swoją prawomocność dopiero po przyjęciu ich przez Stolicę Apostolską. To przekonanie Rzymu odnośnie wszystkich synodów, także tych ekumenicznych - kontrastuje i prowadzi do zderzenia z przeciwnymi wschodnimi wyobrażeniami i będzie prowadzić do podziału pomiędzy prawosławnym a katolickim Kościołem.

Ale jeszcze biskupi pięciu głównych Kościołów Cesarstwa Rzymskiego zachowują w zasadzie wzajemną communio. Od VI wieku wprowadzają oni tytuł „patriarchy” ${ }^{27} \mathrm{i}$ tworzą w ramach konstytucji Kościoła wczesnego średniowiecza tzw. „pentarchię” albo „władzę pięciu”" Ważność i kolejność poszczególnych patriarchatów wyraża się następująco: 1. Rzym, 2. Konstantynopol, 3. Aleksandria, 4. Antiochia, 5. Jerozolima. Na trzecim soborze w Konstantynopolu (680-681) wygrywa ostatecznie przekonanie, że sobór nabiera znaczenia ekumenicznego tylko wtedy, jeżeli udział w nim biorą przedstawiciele wszystkich pięciu patriarchatów.

W odróżnieniu od patriarchatów cesarskich nie ma nigdzie mowy o poszerzeniu rzymskiej jurysdykcji. Rzym odrzuca takie traktowanie go powołując się na tekst Mt 16, $18 \mathrm{n}$. i odrzuca dyskusję na soborach nad należnymi mu przywilejami władzy. Zależnie od tego, jaka w owym czasie była łączność nawet w bezpośrednim obszarze wpływów rzymskich - odpowiednio do różnorodności poszczególnych regionów - mniej lub bardziej silna, ${ }^{29}$ to pomimo tego prowadzą papieże z patriarchatami Wschodu dialog, a zwłaszcza z tymi, którzy zasiadają stolice Piotrowe, które charakteryzują się nie tylko różnicami, ale mniej lub bardziej kolegialnym uznaniem. Ta władza biskupa rzymskiego wykonywana w swej intensywności zależnie od regionu, która uznaje w wysokim stopniu także jako autonomiczną patriarchalną instancję pośrednią, mogłaby w naszych ekumenicznych czasach otworzyć posłudze papieskiej perspektywę twórczego budowania jedności. „Funkcjonować mogą takie pośrednie instancje na trwałe tylko dzięki wysokiej kulturze synodalnej, a jednocześnie także wtedy, gdy

26 Por. Actio VIII, s. 3-17 soboru w Chalcedonie z 26 października 451 roku (wyd. E. Schwartz, Concilium Universale Chalcedonense [ACO 2, 1, 3], Berlin Lepzig 1935, s. 58-75.

27 Co do wprowadzenia tytułu „patriarchy” przez biskupów wymienionych głównych Kościołów por. F. R. Gahbauer, Die Pentarchie Theorie, dz. cyt. , s. 51-58.

28 Por. tu i następne K. Schatz, Primat, dz. cyt., s. 67.

29 Por. jak się kształtował wpływ papieża na różne regiony na Zachodzie, K. Schatz, Primat, dz. cyt., s. 47-52. 
prawnie będą zarezerwowane te obszary, do których rzymskie centra zobowiążą się nie wkraczać lub tylko pod szczególnymi uwarunkowaniami”30.

Tłumaczył z niemieckiego ks. Mieczysław Olszewski

${ }^{30} \mathrm{~K}$. Schatz, Unkonventionelle Gedanken eines Kirchenhistorikers zum päpstlichen Primat, [w:] P. Hünermann (red.), Papstum und Ökumene. Zum Petrusdienst an der Einheit aller Getauften, Regensburg 1997, s. 25-42; tu: 38 i n. 